\title{
UPAYA MENINGKATKAN PRESTASI BELAJAR FISIKA DENGAN PENERAPAN MODEL PEMBELAJARAN PROBLEM SOLVING SISWA KELAS XI-MIA SEMESTER 2 SMA NEGERI 1 DENPASAR
}

\author{
I Gede Sugita \\ SMA Negeri 1 Denpasar \\ Email:sugita_gede@ymail.com
}

\begin{abstract}
ABSTRAK
Prestasi belajar siswa ditunjukkan berdasarkan hasil observasi awal menunjukkan bahwa pembelajaran yang dilakukan belum berjalan secara maksimal.Oleh karena itu untuk meningkatkan prestasi belajar siswa diperlukan model pembelajaran dengan model dan strategi yang tepat. Salah satunya adalah model pembelajaran Problem Solving Penelitian ini bertujuan untuk meningkatkan prestasi belajar siswa. Lokasi penelitian ini di SMA Negeri 1 Denpasar dengan jumlah siswa 46 orang. Data dalam penelitian ini diperoleh dari tes prestasi belajar yang kemudian dilakukan analisis secara deskriptif.Penelitian ini dilaksanakan dalam dua siklus. Setiap siklus dilakukan berdasar tahapan: (1) menyusun rencana kegiatan, (2) melaksanakan tindakan,(3) observasi, dan (4) refleksi.Hasil penelitian menunjukkan bahwa menurut hasil observasi awal pembelajaran siswa kurang aktif, mudah jenuh, dan perhatian siswa pada penjelasan guru sangat kecil sehingga nilai ratarata siswa hanya sebesar 72.97. Setelah tindakan siklus I penguasaan materi pembelajaran meningkat menjadi rata-rata 78,24 dengan siswa tuntas 27 siswa dan belum tuntas 10 siswa. Hasil tindakan pada siklus II penguasan materi setelah diberikan tes prestasi belajar meningkat menjadi rata-rata 84,19 dengan siswa tuntas 35 orang dan 2 orang siswa belum tuntas. Presentase ketuntasan belajar pada siklus II ini telah memenuhi indikator keberhasilan yang ditetapkan dan siklus dinyatakan tidak dilanjutkan,dengan kesimpulan bahwa pemanfaatan model pembelajaran Problem Solving telah mampu dengan baik untuk dijadikan alternatif dalam meningkatkan prestasi belajar siswa.
\end{abstract}

Kata Kunci : Model Pembelajaran Problem Solving dan Prestasi Belajar Fisika Siswa.

\begin{abstract}
Student achievement is shown by the results of the initial observations indicate that learning is done not run maXI-MIAmum. Therefore to improve student achievement required learning model with the model and the right strategy. One is the learning model of Problem Solving This study aims to improve student achievement. The location of this research at SMA Negeri 1 Denpasar with the number of students 46 people. The data in this study were obtained from the learning achievement test which is then carried deskriptif. The research analysis was conducted in two cycles. Each cycle is done based on the following steps: ( 1 ) develop a plan of activities, ( 2 ) carry out actions , (3) observation, and ( 4 ) refleksi. The result of research shows that according to the preliminary observations of student learning outcomes are less active, easily bored, and the students' attention on teacher's explanation is so small that the average value of 72.97 students only. After the first cycle measures mastery learning materials increased to an average of 78,24 with 27 students and the students completed the unfinished 10 students. The results of the action in the second cycle after the material mastery learning achievement test given rise to an average of 84.19 with 35 students completed and unfinished 2 students. Percentage of mastery learning in the second cycle is in compliance with defined indicators of success and the cycle is declared not followed, with the conclusion that the use of problem solving learning model has been able to either to be used as an alternative in improving student achievement .
\end{abstract}

Keywords : Problem Solving and Learning Model Physics Student Achievement . 


\section{PENDAHULUAN}

Pendidikan di sekolah memegang peranan penting dalam rangka mewujudkan tercapainya keberhasilan secara optimal seperti yang diharapkan. Proses belajar mengajar merupakan inti dari proses pendidikan. Dalam proses belajar mengajar tersebut guru menjadi pemeran utama dalam menciptakan situasi interaktif yang edukatif, yakni interaksi antara guru dengan siswa, siswa dengan siswa dan dengan sumber pembelajaran dalam menunjang tercapainya tujuan belajar.

Kenyataan yang di lapangan sangat jauh berbeda. Hasil yang diperoleh menyangkut penguasaan materi pelajaran pada semester 2 siswa Kelas XI-MIA SMA Negeri 1 Denpasar pada mata pelajaran Fisika ternyata masih belum mencapai standar minimal seperti yang ditetapkan. Prestasi belajar mereka baru mencapai ratarata 72,97 yaitu di bawah KKM pada mata pelajaran Fisika Tahun Pelajaran 2017/2018di sekolah ini yaitu 75. Daya serap siswa terhadap materi pelajaran berbicara hanya $64,86 \%$ atau 24 siswa tergolong berhasil mencapai ketuntasan belajar sesuai yang diharapkan sementara 13 siswa atau $35,14 \%$ tergolong tidak tuntas.

Adapun langkah yang diambil untuk memperbaiki prestasi belajar siswa yaitu dengan tindakan perbaikan yang selanjutnya disusun dalam bentuk penelitian tindakan kelas dengan penggunaan Model Pembelajaran Problem Soving untuk meningkatkan prestasi belajar siswa kelas XI-MIA semester 2 SMA Negeri 1 Denpasar Tahun ajaran 2017/2018. Dengan cara ini diharapkan anak akan tertarik untuk berinteraksi dalam pembelajaran sehingga akan meningkatkan kemampuan dan keterampilannya. Rumusan masalah dalam penelitian ini terurai sebagai berikut: Apakah model pembelajaran Problem Solving dapat meningkatkan prestasi belajar siswa kelas XI-MIA Semester 2 SMA Negeri 1 Denpasar Tahun Pelajaran 2017/2018?

Penggunaan pendekatan pembelajaran, strategi pembelajaran, model pembelajaran yang baik, metode-metode ajar yang cocok dalam penerapannya di lapangan dan menggunakan teknik yang tepat diupayakan sebagai cara pemecahan masalah penelitian ini. Model pembelajaran Problem Solving merupakan salah satu dari banyak cara yang bisa dilakukan guru dalam upaya meningkatkan mutu pembelajaran. Model ini mempunyai langkah-langkah yang mendorong keaktifan siswa dalam belajar dengan cara berkelompok.

Berdasar uraian ini jelas bahwa model pembelajaran Problem Solving menuntut kemampuan siswa untuk giat mempelajari apa yang disampaikan guru, mampu menampilkan dirinya di depan siswa-siswa yang lain. Dipihak lain, untuk dapat menyelesaikan tuntutan tersebut, inovasi yang dilakukan guru akan sangat menentukan. Inovasi tersebut berupa tuntunan-tuntunan, pemberian fasilitasfasilitas, motivasi-motivasi, interpretasi serta kemampuan implementasi yang tinggi. Langkah-langkah inilah yang dapat digunakan memecahkan masalah penelitian.

Tujuan penelitian ini adalah untuk mengetahui seberapa besar peningkatan prestasi belajar yang terjadi setelah langkah-langkah Model Pembelajaran 
Problem Solving dilaksanakan dalam proses belajar mengajar. Manfaat secara teoritis yang dapat dinikmati dari hasil penelitian ini diharapkan sebagai acuan dalam memperkaya teori untuk peningkatan kompetensi guru. Sedangkan secara praktis penelitian ini diharapkan bermanfaat.

Ada beberapa hal yang perlu diperhatikan dalam pembelajaran pemecahan masalah yakni: 1) menentukan permasalahan yang akan disajikan disesuikan dengan materi, 2) masalah yang disajikan harus mampu mendorong siswa berpikir dari berbagai sudut pandang yang berbeda, 3) masalah harus disesuaikan dengan dengan tingkat kemampuan siswa, 4) masalah harus jelas, 5) masalah dikaitkan dengan dunia nyata dan cukup menarik siswa (Cholis (2002) dalam Wardani (2011)

Ciri kelas yang melaksanakan pembelajaran adalah: 1) siswa secara aktif terlibat dalam pembelajaran, 2) siswa belajar dari temannya melalui kerja kelompok, diskusi, saling mengkoreksi, 3) pembelajaran menekankan pada masalah bersifat terbuka, 4) prilaku siswa dibangun atas kesadaran diri dan hadiah untuk prilaku baik adalah kepuasan diri, 5) siswa menggunakan kemampuan berpikir kritis dan kreatif terlibat penuh dan ikut bertanggung jawab dalam mengayakan terjadinya proses pembelajaran yang efektif, 6) penghargaan terhadap pengakuan siswa sangat diharapkan (Nur, 2003).

Dalam buku Evaluasi Pendidikan (Depdiknas, 2009) pemecahan masalah merupakan bagian dari Kurikulum Matematika yang sangat penting karena dalam proses pembelajaran maupun penyelesaiannya, siswa dimungkinkan memperoleh pengalaman menggunakan pengetahuan serta keterampilan yang sudah dimiliki untuk diterapkan pada pemecahan masalah yang bersifat tidak rutin. Melalui kegiatan ini aspek-aspek kemampuan matematika yang penting seperti penerapan aturan pada masalah tidak rutin, penemuan pola, penggeneralisasian, komunikasi matematika dan lain-lain dapat dikembangkan secara lebih baik.

Lebih lanjut dijelaskan bahwa tujuan diberikan pelajaran matematika adalah agar siswa mampu menghadapi perubahan-perubahan keadaan yang selalu berkembang melalui latihan bertindak atas dasar pemikiran logis, rasional, kritis, cermat, jujur dan efektif. Pelajaran diutamakan yang bersifat riil atau alamiah, dengan tema-tema permasalahan yang diambil dari kejadian sehari-hari yang dekat dengan kehidupan siswa. Selain itu, proses pemecahan masalah sebaiknya dilakukan dalam kelompok-kelompok kecil, sehingga mamberi peluang untuk berdiskusi dan saling bertukar pendapat yang dapat mengembangkan kemampuan berkomunikasi.

Djamarah (1994) mendefinisikan prestasi belajar sebagai hasil yang diperoleh berupa kesan-kesan yang mengakibatkan perubahan dalam diri individu sebagai hasil dari aktivitas dalam belajar. Kalau perubahan tingkah laku adalah tujuan yang mau dicapai dari aktivitas belajar, maka perubahan tingkah laku itulah salah satu indikator yang dijadikan pedoman untuk mengetahui kemajuan individu dalam segala hal yang diperolehnya di sekolah. Dengan kata lain prestasi belajar merupakan kemampuankemampuan yang dimiliki oleh siswa sebagai akibat perbuatan belajar atau setelah menerima pengalaman belajar, yang 
dapat dikatagorikan menjadi tiga ranah, yakni ranah kognitif, afektif, dan psikomotor.

Sardiman (1988) menyatakan prestasi belajar sangat vital dalam dunia pendidikan, mengingat prestasi belajar itu dapat berperan sebagai hasil penilaian dan sebagai alat motivasi. Adapun peran sebagai hasil penilaian dan sebagai alat motivasi diuraikan seperti berikut.

Kemampuan guru menentukan permasalahan yang akan disajikan tidaklah gampang. Guru harus mampu membimbing siswanya agar pembelajaran bisa berjalan sesuai harapan. Apabila guru telah melakukan inovasi-inovasi untuk mematangkan siswanya memperoleh kemampuan yang diharapkan dalam menampilkan sesuatu tentu dapat diharapkan para siswa akan memiliki kebiasaan-kebiasaan, keterampilanketerampilan berpikir tingkat tinggi yang dibutuhkan. Untuk dapat terwujudnya apa yang diharapkan tersebut, inovasi langkahlangkah yang diupayakan guru akan dapat memecahkan permasalahan yang ada. Dasar berpikir inilah yang dijadikan acuan dalam memecahkan masalah yang sedang diteliti.

Berdasarkan kajian dariberbagai teori, kajian hasil penelitian yang pernah dilakukan dalam masalahyang serupa, diskusi dengan teman sejawat atau dengan pakar, serta refleksipengalaman sendiri sebagai guru yang diduga dapat digunakan untuk menyelesaikan masalah yang sedang dihadapi,dijadikan dasar untuk menyusun alternatif tindakan dalam bentuk hipotesis sebagai berikut: "Apabila langkah-langkah model pembelajaran Problem Solving diterapkan dengan maksimal maka prestasi belajar siswa dapat ditingkatkan".

\section{METODELOGI PENELITIAN}

Peneliti mengambil lokasi penelitian di SMA Negeri 1 Denpasar Kelas XI-MIA Semester 2 Tahun Pelajaran 2017/2018. Sekolah ini terletak di Jalan Kamboja Denpasar. Rancangan mengenai siklus tersebut menggunakan Model Kemmis dan Mc. Taggart seperti terlihat pada gambar 1

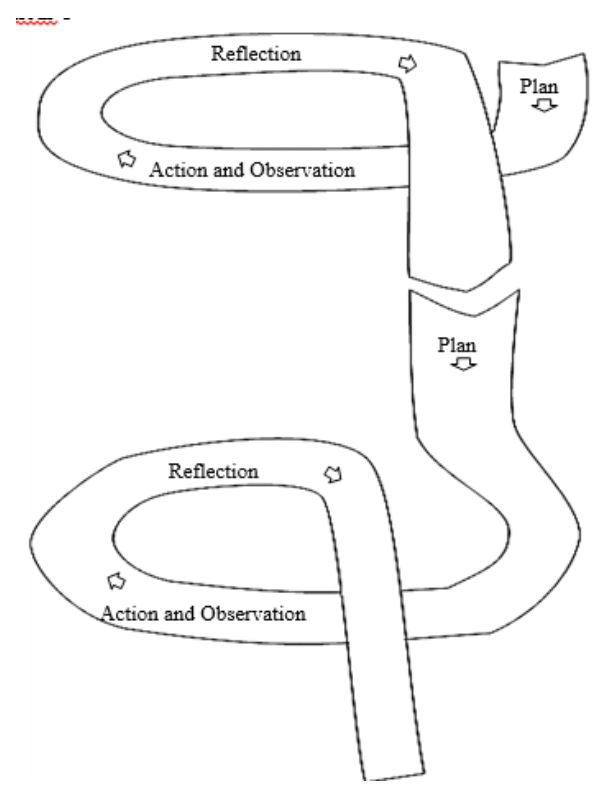

Gambar 1. Desain PTK Model Kemmis dan Mc. Taggart (dalam Hamzah B. Uno dkk, 2011)

Berdasar rancangan diatas maka langkah yang dilakukan adalah berlangsung dalam dua siklus dan masing-masing siklus terdiri dari perencanaan, pelaksanaan, observasi/pengamatan dan refleksi. Hamzah dkk (2011) menulis bahwa model Kemmis dan Mc. Taggart merupakan pengembangan dari konsep dasar yang diperkenalkan oleh Kurt Lewin. Hanya saja, komponen acting (tindakan) dengan observing (pengamatan) dijadikan satu kesatuan.

Peneliti mengambil subjek penelitian siswa kelas XI-MIA semester 2 
SMA Negeri 1 Denpasar Tahun pelajaran 2017/2018. Adapun objek dalam penelitian ini adalah peningkatan prestasi belajar siswa kelas XI-MIA Semester SMA Negeri 1 Denpasar setelah diterapkan Model Pembelajaran Problem Solving dalam proses pembelajaran. Adapun pelaksanaan penelitian tindakan kelas ini dimulai dari bulan Januari sampai bulan Juni 2018. Data hasil penelitian ini dikumpulkan dengan tes prestasi belajar.

Cara yang dilakukan dalam menganalisis data pada penelitian ini adalah deskriptif. Untuk data kuantitatif dianalisis dengan mencari mean, median, modus, membuat interval kelas dan melakukan penyajian dalam bentuk tabel dan grafik. Data hasil Penelitian Tindakan Kelas ini dikumpulkan melalui tes prestasi belajar sebagai instrumen penelitian. Dengan rata-rata nilai siswa pada siklus I mencapai 78,24 dan pada siklus II mencapai 84,19 maka penelitian ini sudah dianggap berhasil.

\section{HASIL PENELITIAN DAN PEMBAHASAN}

\section{Hasil Penelitian}

Perolehan data awal dapat dijelaskan : hanya 24 orang siswa ( 64,86 $\%$ ) yang memperoleh penilaian sesuai ratarata KKM, yang 13 orang siswa ( $35,14 \%$ ) belum mampu mencapai hasil sesuai KKM yang ditanyakan. Prosentase tersebut menunjukkan rendahnya prestasi siswa pada awalnya dalam menerpa ilmu pada mata pelajaran Fisika. Gambaran dari data awal tersebut sudah barang tentu menuntut guru untuk bekerja lebih giat dan lebih keras dalam memperbaiki tingkat kemampuan mereka jika mau mengharapkan agar anak-anak dapat tumbuh dan berkembang sesuai dengan yang diharapkan.

\section{Observasi/Pengamatan Siklus I}

Untuk hasil dari observasi terhadap siswa diamati secara berkelanjutan dengan peneliti terus memperhatikan semua siswa yang diteliti, gerak-gerik mereka, pakaian mereka, kehadiran pada pagi hari dan terus memantau dengan lembar observasi yang telah penulis siapkan.

\section{Refleksi Siklus I}

Refleksi merupakan kajian secara menyeluruh tindakan yang telah dilakukan berdasarkan data yang telah terkumpul, kemudian dilakukan evaluasi guna menyempurnakan tindakan.Refleksi menyangkut analisis, sintesis, dan penilaian terhadap hasil pengamatan atas tindakan yang dilakukan (Hopkin, dalam Arikunto, 2006).

Analisis kuantitatif Prestasi belajar siswa siklus I

1. Rata-rata (mean) dihitung dengan:

$$
\frac{\text { Jumlah willai }}{\text { Jwmlah siswa }}=2895 / 37=78,24
$$

2. Median (titik tengahnya) dicari dengan mengurut data/nilai siswa dari yang terkecil sampai terbesar. Setelah diurut apabila jumlah data ganjil maka mediannya adalah data yang ditengah. Kalau jumlahnya genap maka dua data yang di tengah dijumlahkan dibagi 2 (dua). Untuk median yang diperoleh dari data siklus I dengan menggunakan cara tersebut adalah: 80

3. Modus (angka yang paling banyak/paling sering muncul) setelah diasccending/diurut angka tersebut adalah: 80 
4. Untuk persiapan penyajian dalam bentuk grafik maka hal-hal berikut dihitung terlebih dahulu.

1. Banyak kelas $(\mathrm{K})=1+3,3 \times \log$ $(\mathrm{N})$

$$
\begin{gathered}
=1+3,3 \times \log \\
37 \\
=1+3,3 \times 1.58 \\
=1+5.18= \\
\quad 6.18 \rightarrow 6
\end{gathered}
$$

2. Rentang kelas $(r)=$ skor maksimum - skor minimum

$$
\begin{aligned}
& =90-65 \\
& =25
\end{aligned}
$$

3. Panjang kelas interval (i) = $\mathrm{r} / \mathrm{k}=25 / 6=4,17$

4. Tabel 05. Data Kelas Interval Siklus I

\begin{tabular}{ccccc}
\hline No & Interval & Nilai & Frekuensi & Frekuensi \\
Urut & & Tengah & Absolut & Relatif \\
1 & $62-66$ & 64 & 4 & 10,81 \\
2 & $67-71$ & 69 & 6 & 16,22 \\
3 & $72-76$ & 74 & 3 & 8,11 \\
4 & $77-81$ & 79 & 13 & 35,14 \\
5 & $82-86$ & 84 & 8 & 21,62 \\
6 & $87-91$ & 89 & 3 & 8,11 \\
& Total & & 37 & 100 \\
\hline
\end{tabular}

\section{Penyajian dalam bentuk grafik/histogram}

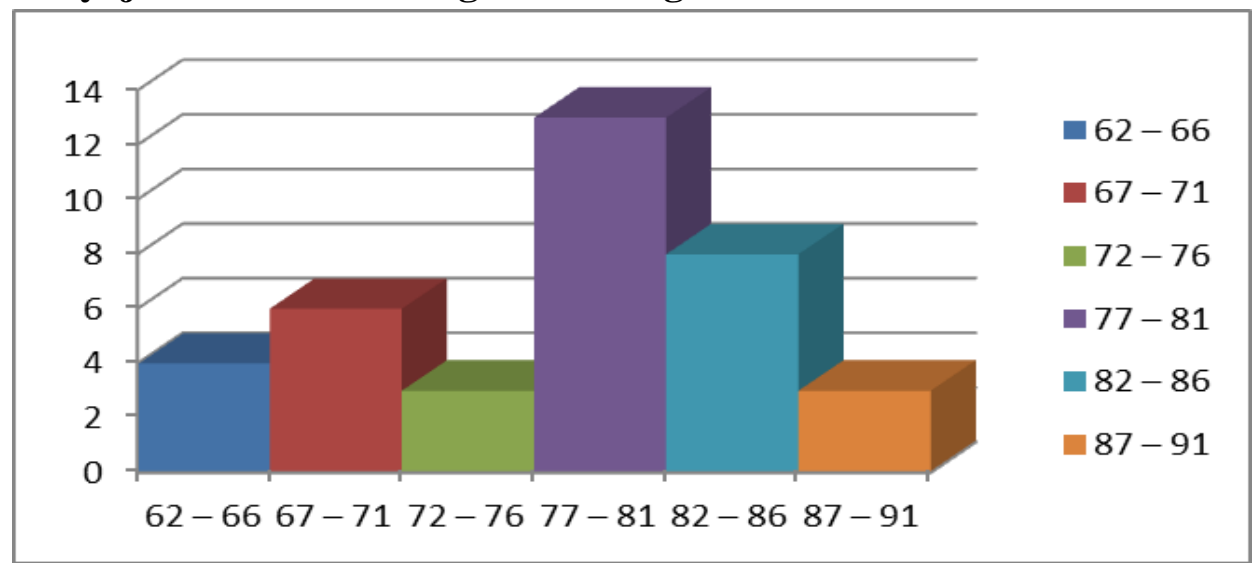

Gambar 02. Histogram Prestasi Belajar Fisika siswa kelas XI-MIA semester 2 tahun ajaran 2017/2018SMA Negeri 1 Denpasar Siklus I

Mengikuti penegasan Depdiknas (2011) bahwa pada Bab IV direkam kegiatan masing-masing siklus diserta data lengkap beserta aspek-aspek yang direkam/diamati. Rekaman itu menunjukkan adanya perubahan akibat tindakan yang diberikan. Pada refleksi di akhir setiap siklus berisi penjelasan tentang aspek keberhasilan dan kelemahan yang terjadi dalam bentuk grafik. Kemukakan adanya perubahan/ kemajuan/perbaikan yang terjadi pada diri siswa, lingkungan kelas, guru sendiri, minat, motivasi belajar dan hasil belajar.Untuk bahan dasar analisis dan pembahasan kemukakan hasil kelemahan siklus ke dalam ringkasan tabel/grafik. Data tabel/grafik rangkuman itu akan dapat memperjelas perubahan yang terjadi disertai pembahasan secara rinci dan jelas. Selain penegasan dari Depdiknas tersebut pendapat ahli juga sama dengan pendapat tersebut. Arikunto (2006) menjelaskan bahwa pada Bab IV perlu menyampaikan uraian yang lengkap mulai dari perencanaan, pelaksanaan, pengamatan 
dan refleksi yang berisi penjelasan tentang aspek-aspek keberhasilan dan kelemahan yang terjadi.

\section{Observasi/Pengamatan II}

\section{Refleksi Siklus II}

Analisis kuantitatif Prestasi belajar siswa siklus II

1. Rata-rata (mean) dihitung dengan:

$$
\frac{\text { Jumlah wilai }}{\text { Jumlah siswa }}=3115 / 37=84,19
$$

2. Median (titik tengahnya) dicari dengan mengurut data/nilai siswa dari yang terkecil sampai terbesar. Setelah diurut apabila jumlah data ganjil maka mediannya adalah data yang ditengah. Kalau jumlahnya genap maka dua data yang di tengah dijumlahkan dibagi 2 (dua). Untuk median yang diperoleh dari data siklus I dengan menggunakan cara tersebut adalah: 85

3. Modus (angka yang paling banyak/paling sering muncul) setelah diasccending/diurut. Angka tersebut adalah: 85

4. Untuk persiapan penyajian dalam bentuk grafik maka hal-hal berikut dihitung terlebih dahulu. i. Banyak kelas $(\mathrm{K})=1+3,3 \mathrm{x}$ $\log (\mathrm{N})$

$$
\begin{aligned}
= & 1+3,3 \times \log \\
& 37 \\
= & 1+3,3 \times \\
& 1.58 \\
= & 1+5.18= \\
& 6.18 \rightarrow 6
\end{aligned}
$$

ii. Rentang kelas (r) = skor maksimum - skor minimum

$$
\begin{aligned}
& =95-70 \\
& =25
\end{aligned}
$$

iii. Panjang kelas interval (i) = $\mathrm{r} / \mathrm{k}=25 / 6=4,17$

iv. Tabel 07. Data Kelas Interval Siklus II

\begin{tabular}{ccccc}
\hline No & Interval & $\begin{array}{c}\text { Nilai } \\
\text { Tengah }\end{array}$ & Frekuensi & Freksolut \\
Urut & & Telatif & Rela \\
1 & $68-72$ & 70 & 2 & 5,41 \\
2 & $73-77$ & 75 & 4 & 10,81 \\
3 & $78-82$ & 80 & 6 & 16,22 \\
4 & $83-87$ & 85 & 13 & 35,14 \\
5 & $88-92$ & 90 & 10 & 27,03 \\
6 & $93-97$ & 95 & 2 & 5,41 \\
& Total & & 37 & 100 \\
\hline
\end{tabular}

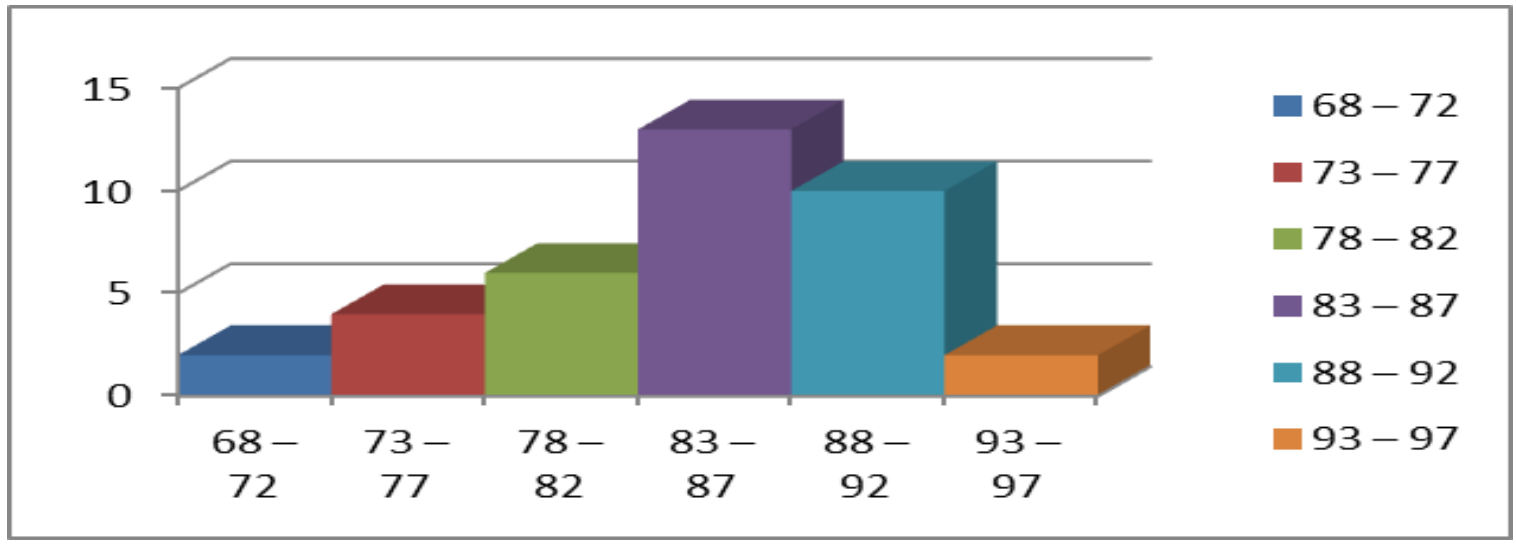

Gambar 03. Histogram Prestasi Belajar Fisika siswa kelas XI-MIA .semester 2 tahun ajaran 2017/2018SMA Negeri 1 Denpasar Siklus II 


\section{PEMBAHASAN}

\section{Hasil yang diperoleh siklus I}

Sesuai peroleh data awal yang amat rendah yang belum sesuai dengan harapan dan tuntutan indikator keberhasilan penelitian akibat hal-hal yang sudah diupayakan pada latar belakang masalah, maka pada siklus I diupayakan perbaikan dengan memilih Model Pembelajaran Problem Solving. Model ini diupayakan pelaksanaannya di lapangan secara maksimal dengan mengikuti teori-teori yang ada. Kendala yang ada adalah pada diri guru yang berlum terbiasa untuk melaksanakan dengan model yang baru ini dan masih terlintas pada pikiran bahwa tugas guru adalah mengajar dan belum betul-betul dimengerti bahwa sesuai aturan Permen yang baru tugas guru adalah membelajarkan. Kebiasaan ini masih muncul dan mendominasi pembelajaran pada siklus I. Peneliti pada siklus I ini masih tetap berdiri di depan kelas memperlihatkan diri bahwa kegiatan lebih pada mengajar. Hal ini akhirnya dipecahkan dengan kembali berdiskusi dengan guru-guru, bertanya jawab baik pada saat pertemuan awal maupun pada saat dilakukan pertemuan balikan. Peneliti giat melakukan diskusi, memberi pengertian-pengertian pada siswa dalam upaya menstimulir kegiatan yang dilakukan demi adanya perbaikan. Setelah giat dilakukan upaya untuk perbaikan akhirnya pada siklus I ini nilai siswa dapat meningkat walaupun belum sesuai harapan sesuai usulan keberhasilan penelitian. Kemampuan siswa awal dengan nilai ratarata 72.97 , akhirnya pada siklus I ini dapat ditingkatkan menjadi rata-rata 78,24 dengan ketuntasan belajar sebesar 72,97 \%. kekurangan-kekurangan yang ada adalah masih terasa dominasi guru dalam pembelajaran, siswa belum giat bekerja, bertanya, berargumentasi, alat peraga/media belum mampu dioperasikan secara maksimal.

\section{Hasil yang diperoleh dari siklus II}

Upaya yang lebih giat yang bisa peneliti laksanakan pada siklus yang kedua ini berpenekanan pada perbaikan-perbaikan dari kekurangan-kekurangan yang ada pada diri siswa maupun pada diri guru. Semua kekurangan pada siklus I yang sudah disampaikan menjadi acuan bagi peneliti untuk melakukan perbaikan. Perbaikan ini banyak dilakukan seperti membuat perencanaan pembelajaran yang lebih baik sebelum mereka masuk kelas. Pada saat melaksanakan proses pembelajaran bimbingan terus diupayakan diberi penekanan agar peserta didik merubah cara yang mereka belajar selama ini yaitu giat bekerja, giat mencari tahu, giat mengoptimalkan waktu pembelajaran untuk dapat menguasai materi yang diberikan. Jadi guru tidak diharapkan untuk menceramahkan materi, guru tidak diharapkan menghabiskan waktunya untuk berdiri di depan kelas dan ngomong a, b, c, terus menerus mendominasi kelas. Yang dituntut adalah lebih $75 \%$ waktu digunakan oleh siswa untuk memperoleh pengalaman belajar, jadi guru boleh duduk di bangku guru dan tidak harus terus menerus berdiri ngomong ini, ngomong itu sampai habis waktu pembelajaran tetap juga berdiri. Pada pelaksanaan pembelajaran di siklus ini, bimbingan diupayakan lebih maksimal, arahan-arahan diberikan, tugas-tugas diberikan yang lebih menantang, giat 
bertanya terhadap apa yang belum mampu dikuasai, mengupayakan pembelajaran yang menyenangkan, yang interaktif, inspiratif serta memberi ruang yang banyak bagi peserta didik untuk berkreasi, menyalurkan bakat serta memupuk keberhasilan siswa untuk berargumentasi, bentukan pendapat semua ini diupayakan dalam upaya memperbaiki kekurangan-kekurangan yang ada selama siklus I. Disamping itu peserta didik juga diminta untuk memperhatikan waktu dan tidak membuang-buang waktu pembelajaran. Diskusi yang matang arahanarahan, bimbingan-bimbingan yang dilakukan ternyata mampu menghasilkan peningkatan yang cukup signifikan. Dari rata-rata siklus I 78,24 pada siklus yang ke II ini naik menjadi 84,19. Keberhasilan ini tidak terlepas dari upaya yang sungguhsungguh, upaya yang maksimal yang dapat ditujukan untuk peningkatan mutu pendidikan. Dari hasil tersebut, rumusan masalah disampaikan maupun dijawab, begitu juga tujuan penelitian mampu diupayakan. Dengan hasil tersebut maka hipotesis tindakan yang diajukan mampu dibuktikan kebenarannya. Oleh karenanya penelitian ini tidak dilanjutkan ke siklus berikutnya.

\section{SIMPULAN DAN SARAN Simpulan}

Simpulan yang dapat disampaikan berdasarkan semua hasil analisis data yang telah dilakukan dengan melihat hubungan rumusan masalah, tujuan penelitian, hipotesis tindakan dan semua hasil pembahasan adalah sebagai berikut:

1. Fokus pembahasan dari penelitian ini adalah untuk membuktikan apakah
Model Pembelajaran Problem Solving dapat meningkatkan Prestasi Belajar Fisika. Dari hasi analisis yang telah dilakukan yang dilanjutkan dengan pembahasan dapat disampaikan bahwa peningkatan hasil belajar telah dapat diupayakan. Dari data awal yang ratarata baru mencapai 72.97 dan jauh dari kriteria ketuntasan minimal pada mata pelajaran ini, pada siklus I sudah dapat ditingkatkan menjadi 78,24 dan pada siklus II sudah mencapai rata-rata 84,19. Siswa yang pada awalnya kemampuannya masih sangat rendah dimana hanya ada 24 yang tuntas, pada siklus I sudah dapat ditingkatkan yaitu ada 27 siswa yang sudah tuntas dan pada siklus II sudah 35 yang tuntas. Dari hasil awal ada 13 siswa yang harus diremidi sedangkan pada siklus II hanya 2 siswa yang mesti diremidi.

2. Dari uraian fakta-fakta di atas yang dibarengi dengan penyajian data hasil observasi baik siklus I maupun siklus II yang disampaikan pada Bab IV telah dapat dibuktikan bahwa Model Pembelajaran Problem Solving dapat meningkatkan kemampuan siswa dalam belajar. Dengan hasil tersebut dapat dibuktikan bahwa rumusan masalah dan tujuan penelitian telah tercapai dan hipotesis yang diajukan sudah dapat diterima. Untuk hal tersebut selanjutnya perlu disampaikan saran.

\section{Saran}

Berdasarkan temuan yang sudah disimpulan dari hasil penelitian, dalam upaya mencapai tujuan pembelajaran, dapat disampaikan saran-saran sebagai berikut: 
1. Bagi guru kelas, apabila mau melaksanakan proses pembelajaran penggunaan metode yang telah diterapkan ini semestinya menjadi pilihan dari beberapa metode yang ada mengingat metode ini telah terbukti dapat meningkatkan kualitas pembelajaran.

2. Bagi peneliti lain, walaupun penelitian ini sudah dapat membuktikan efek utama dari Model Pembelajaran Problem Solving dalam meningkatkan prestasi belajar, sudah pasti dalam penelitian ini masih ada hal-hal yang belum sempurna dilakukan, oleh karenanya kepada peneliti lain yang berminat meneliti topik yang sama untuk meneliti bagianbagian yang tidak sempat diteliti.

3. Bagi pengembang pendidikan, selanjutnya untuk adanya penguatanpenguatan, diharapkan bagi peneliti lain untuk melakukan penelitian lanjutan guna verifikasi data hasil penelitian ini.

\section{DAFTAR PUSTAKA}

Arikunto, S.; Suhardjono; Supardi. (2006). Penelitian tindakan kelas. Jakarta: PT Bumi Aksara.

Depdiknas.(1999). Pengelolaan pengujian bagi guru mata pelajaran.Jakarta: Direktorat Pendidikan Menengah Umum, Direktorat Jenderal Pendidikan Dasar dan Menengah

Djamarah, S. B. (2002). Prestasi belajar dan kompetensi guru. Surabaya: Usaha Nasional.

Nur, M. et al. (2007). Pengembangan Model Pembelajaran IPA Berorientasi Masalah Kontekstrual untuk Meningkatkan Daya Nalar Mahasiswa dalam Rangka Menyongsong Masyarakat IPTEK pada Pembangunan Jangka Panjang Tahap Kedua. Makalah. Disampaikan pada Seminar Hasilhasil Penelitian Unggulan. IKIP Negeri Surabaya.

Sardiman, A.M. (1988). Interaksi dan motivasi belajar-mengajar pedoman bagi guru dan calon guru. Jakarta: Rajawali Pers.

Wardani D. R. K. (2001). Pengaruh Metode Pembelajaran Proglem Solving dan Group Investigation terhadap Keterampilan Berpikir Tingkat Tinggi dengan Mempertimbangkan Kreativitas pada Siswa Kelas VIII SMP Negeri 3 Denpasar Tahun Ajaran 2010/2011. Tesis. Universitas Pendidikan Ganesha Program Pascasarjana Singaraja. 